\title{
Maytenus salicifolia Reissek (Celastraceae): Evaluation of the Activity of Extracts and Constituents against Helicobacter pylori and Oral Pathogenic Microorganisms
}

\author{
Magalhães, C. G.;* Silva, G. D. F.; Duarte, L. P.; Takahashi, J. A.; Santos, \\ V. R.; Figueiredo, R. C.; Vieira Filho, S. A.
}

Rev. Virtual Quim., 2016, 8 (5), 1524-1536. Data de publicação na Web: 8 de agosto de 2016

http://rvq.sbq.org.br

\begin{abstract}
Maytenus salicifolia Reissek (Celastraceae): Avaliação da Atividade de Extratos e Constituintes contra Helicobacter pylori e Micro-organismos Patogênicos da Cavidade Oral
\end{abstract}

Resumo: Maytenus salicifolia Reissek é conhecida como "cafezinho" em Minas Gerais, Brasil. Suas folhas são utilizadas na medicina popular no tratamento de úlceras estomacais. Neste trabalho é reportado o isolamento de $4^{\prime}-0$ metilepigalocatequina (1) e proantocianidina $A(\mathbf{2})$ dos extratos polares da raiz $(\mathbf{1} ; 4,36 \% ; \mathbf{2}, 2,17 \%)$ e tronco $(\mathbf{1}, 4,16 \% ; \mathbf{2}$, $0,26 \%)$ de $M$. salicifolia. Pela primeira vez, esses compostos foram encontrados na raiz dessa espécie. Esses constituintes foram encontrados em quantidades expressivas, o que torna $M$. salicifolia uma fonte alternativa desses compostos. Além disto, a atividade antimicrobiana de extratos polares (etanólico das raízes, etanólico e acetato-etílico dos galhos) e apolares (hexânico das raízes) dessa planta foi avaliada in vitro contra os patógenos da cavidade oral: Candida albicans, Streptococcus mutans, Streptococcus sanguinis e Staphylococcus aureus. Todos os extratos exibiram atividade antimicrobiana e $C$. albicans foi o micro-organismo mais sensível. Os triterpenos nepeticina, rigidenol, gloquidona, 11-

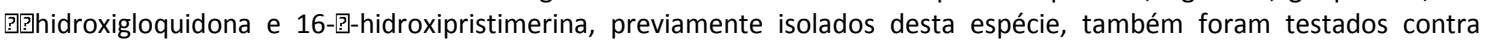
Helicobacter pylori. Rigidenol e 16-?]-hidroxipristimerina foram ativos contra essa bactéria. Os resultados contribuem para confirmar o uso na medicina popular de $M$. salicifolia no tratamento de úlceras e outros problemas estomacais e indicam que extratos dessa planta apresentam grande potencial para o uso no tratamento de doenças infecciosas da cavidade oral.

Palavras-chave: salicifolia; Celastraceae; propriedades antimicrobianas; Helicobacter pylori; patógenos orais.

\begin{abstract}
Maytenus salicifolia Reissek is known as "cafezinho" in Minas Gerais State, Brazil. Its leaves have been used in folk medicine to treat stomach ulcers. The present study reports the isolation of 4 '-O-methylepigallocatechin (1) and proanthocyanidin A (2) of root $(\mathbf{1} ; 4.36 \% ; \mathbf{2}, 2.17 \%)$ and branch $(\mathbf{1}, 4.16 \% ; \mathbf{2}, 0.26 \%)$ polar extracts from M. salicifolia. These compounds were found in the roots of this species for the first time. These constituents were found in large amounts and it makes M. salicifolia a suitable source of these compounds. Moreover, the antimicrobial activity of polar (ethanolic from roots, ethanolic and ethylacetate from branches) and non-polar (hexanic from roots) extracts from this plant was evaluated in vitro against oral pathogens such as Candida albicans, Streptococcus mutans, Streptococcus sanguinis and Staphylococcus aureus. All extracts showed antimicrobial activity and $C$. albicans was the most sensitive microorganism. The triterpenes nepeticin, rigidenol, glochidone, 11- $\alpha$ ? hydroxyglochidone and 16 - $\beta$-hydroxypristimerin, which were previously isolated from this species, were also assayed against Helicobacter pylori. Rigidenol and 16 - $\beta$-hydroxypristimerin exhibited activity against this bacterium. These results contribute to confirm the traditional use of $M$. salicifolia to treat ulcer and other gastrointestinal problems. They also indicated that the extracts from this plant have the potential to be used in the treatment of infectious diseases of the oral cavity.
\end{abstract}

Keywords: M. salicifolia; Celastraceae; antimicrobial properties; Helicobacter pylori; oral pathogens.

* Universidade Estadual de Ponta Grossa, Departamento de Química, Centro de Ciências Exatas e Naturais, Av. Gal. Carlos Cavalcanti, 4748, Uvaranas, CEP 84030-900, Ponta Grossa-PR, Brasil.

$M$ cassiagmag@yahoo.com.br

DOI: $10.21577 / 1984-6835.20160107$

Rev. Virtual Quim. |Vol $8 \mid$ | No. 5| |1524-1536| 


\title{
Maytenus salicifolia Reissek (Celastraceae): Evaluation of the Activity of Extracts and Constituents against Helicobacter pylori and Oral Pathogenic Microorganisms
}

\author{
Cássia G. Magalhães, ${ }^{a, *}$ Grácia D. de Fátima Silva, ${ }^{b}$ Lucienir P. Duarte, ${ }^{b}$

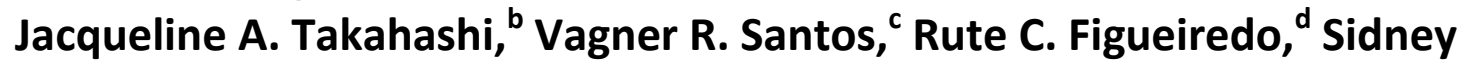
A. Vieira Filho ${ }^{\mathrm{e}}$

${ }^{a}$ Universidade Estadual de Ponta Grossa, Departamento de Química, Centro de Ciências Exatas e Naturais, Av. Gal. Carlos Cavalcanti, 4748, Uvaranas, CEP 84030-900, Ponta Grossa-PR, Brasil;

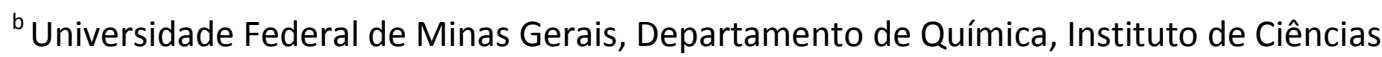
Exatas, Av. Antônio Carlos, 6627, Pampulha, CEP 31270-901, Belo Horizonte-MG, Brasil;

${ }^{\mathrm{C}}$ Universidade Federal de Minas Gerais, Departamento de Clínica Patológica e Cirurgia Odontológica, Faculdade de Odontologia, Av. Antônio Carlos, 6627, Pampulha, CEP 31270-901, Belo Horizonte-MG, Brasil;

dUniversidade Federal de Ouro Preto, Departamento de Química, Instituto de Ciências Exatas e Biológicas, Rua Costa Sena, 171, Centro, CEP 35400-000, Ouro Preto-MG, , Brasil.

e Universidade Federal de Ouro Preto, Departamento de Farmácia, Escola de Farmácia, Rua Costa Sena, 171, Centro, CEP 35400-000, Ouro Preto-MG, Brasil

* cassiagmag@yahoo.com.br

Recebido em 31 de janeiro de 2016. Aceito para publicação em 30 de julho de 2016

1. Introduction

2. Materials and Methods

2.1. General experimental procedures

2.2. Plant material

2.3. Extraction and compound isolation

2.4. Anti oral pathogens activity

2.5. Anti $H$. pylori activity

\section{Results and Discussion}

4. Conclusions

\section{Introduction}

Oral cavity and gastrointestinal diseases are among the main health problems worldwide, many of them are caused by bacteria and fungi. ${ }^{1}$ The yeast Candida albicans and the lactic acid bacterium 
Streptococcus mutans belong to the most common microorganisms found in the oral cavity. ${ }^{2}$ C. albicans is commonly identified in denture-related stomatitis and other forms of oral candidosis, and S. mutans is frequently associated with dental biofilm alterations and is considered one of the most important microorganisms involved in dental caries formation. Another bacterium of this genus, S. sanguinis, contributes for the action of other microorganisms that colonize the tooth surface, forming dental plaque and facilitating the development of caries and periodontal diseases. ${ }^{3}$ Another oral bacterium, Staphylococcus aureus, is related to acute dental infections, such as apical abscesses, jaw osteomyelitis and surgical complications after dental implant procedures. ${ }^{1}$ The high incidence of dental diseases is associated to other factors including the increased resistance of bacteria and fungi to the usual drugs. ${ }^{4}$ Thus, it is necessary to search new, safe, economic and effective options of new compounds to prevent and treat of oral cavity diseases, and natural products, both plant extracts and isolated compounds, represent a good alternative. $^{5}$

Another microorganism of concern to human health is the Gram-negative bacterium Helicobacter pylori, which colonizes the hosts' stomach for their lifetime. It has been acknowledged in the last two decades that this microorganism infects more than half of the world's human population. ${ }^{6} \mathrm{H}$. pylori has been associated to peptic ulcer, gastroduodenal diseases and cancer development, such as gastric adenocarcinoma and mucosa-associated lymphoid tissue (MALT) lymphoma. ${ }^{7}$ In 1994, the World Health Organization classified $H$. pylori as a class I carcinogen for human gastric cancer, and since practically all infected people presented gastritis, it is expected that this bacterium plays a causative role early in the disease progression to adenocarcinoma. ${ }^{8-10}$ Conventional treatments of infections caused by $H$. pylori are carried out based on the association of drugs, such as clarithromycin, amoxicillin, furazolidone, tetracycline and metronidazole, with bismuth or a proton pump inhibitor. ${ }^{11}$ However, the increase in bacterial resistance to antibiotics and the high cost of combined therapy hamper the adoption of this type of treatment in large scale. $^{6}$

In the context of ethnopharmacology, there are many reports about plants used to treat gastrointestinal disorders, especially about species belonging to Maytenus (M.) genus. $M$. aquifolium and $M$. rigida, for instance, presented properties against gastric ulcer. $^{12}$ The medicinal use of $M$. ilicifolia, known in Brazil as 'espinheira-santa', has been reported since the 1920s. ${ }^{13}$ Pharmacological and clinic studies have being carried out since 1988 using extracts and constituents isolated from $M$. ilicifolia. The results are in accordance with scientific and popular experiments and contribute to the efficacy and therapeutic safety of the treatment of this disease. ${ }^{14} \mathrm{M}$. ilicifolia represents one phytotherapic whose pharmacological effects were recognized and established by Central de Medicamentos (CEME) of Ministério da Saúde, Brazil, and its use is totally safe. ${ }^{15}$

$M$. genus is considered the largest group in the Celastraceae family. Up to now, there are about 80 recognized species included in this genus, which are distributed all over the Brazilian territory. ${ }^{16}$ Many biological properties popularly attributed to species of the $M$. genus were also experimentally established, such as antimitotic ${ }^{17}$ and antioxidant activity. ${ }^{18}$

In the state of Minas Gerais, southeastern of Brazil, the leaves of $M$. salicifolia Reissek (Figure 1), commonly known as "cafezinho", have been used in folk medicine to treat stomach ulcers. Decoction of its fresh leaves is popularly used to alleviate itches and skin allergies symptoms. ${ }^{19}$ From branches of $M$. salicifolia was previously reported the isolation of the pentacyclic triterpenes, 30hydroxyfriedelan-3-one, 3,16dioxofriedelane, friedelin, lupeol, betulin and lup-20(29)-en-3,30-diol ${ }^{20}$ and from the roots bark, the chalcone-diterpene adduct salicassin, and a quinone methide 
triterpenoid $\quad 16 \beta$-hydroxypristimerin. ${ }^{21}$ Pentacyclic triterpenes were also found in Austroplenckia populnea, ${ }^{22}$ M. gonoclada, ${ }^{23}$
M. robusta ${ }^{24}$ and other species of the Celastraceae family of natural occurrence in Minas Gerais, Brazil.

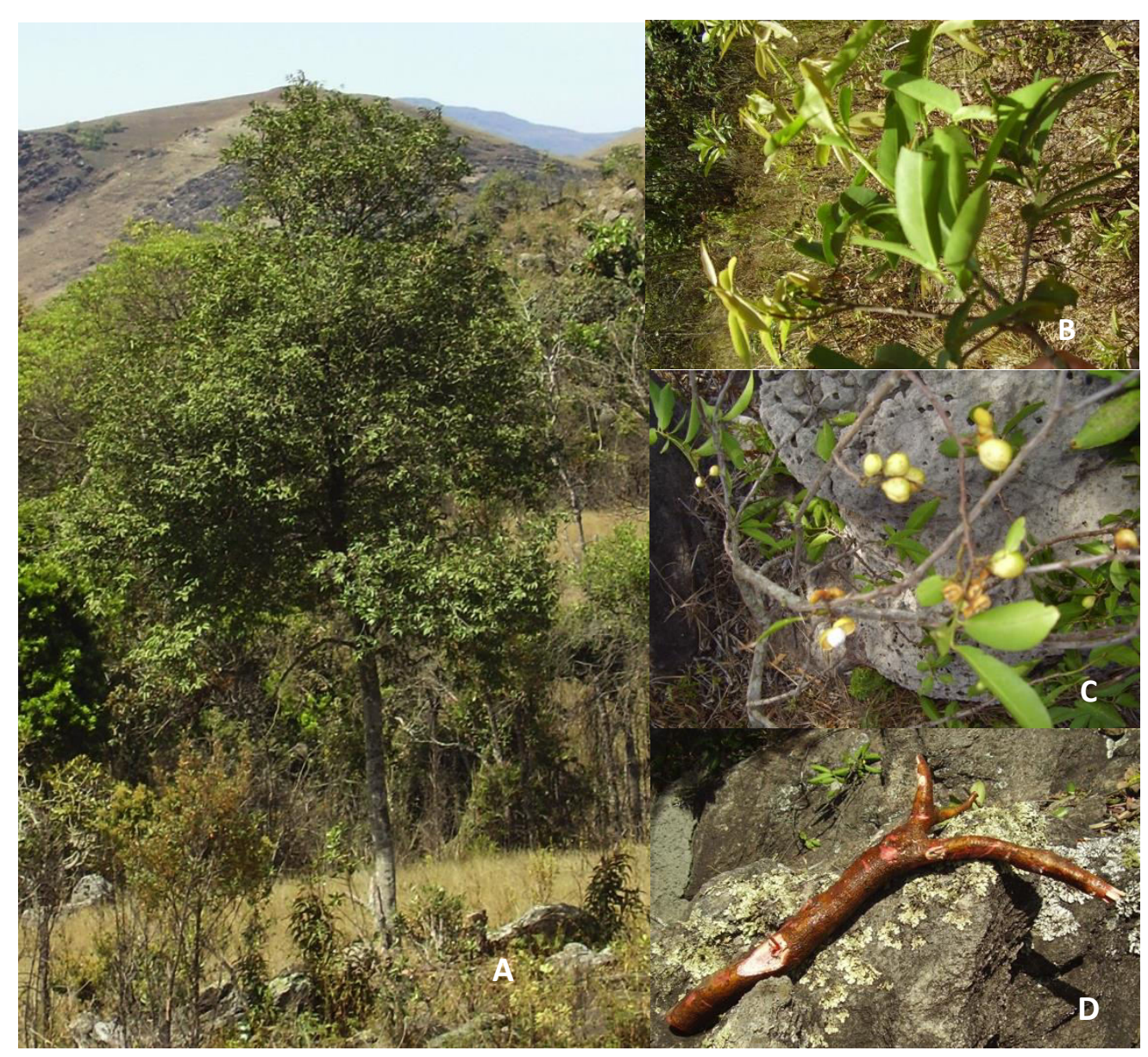

Figure 1. Photos of M. salicifolia Reissek, that is commonly found in Serra de Ouro Branco, MG, Brazil. A: Tree, B: leaves, C: seeds and D: part of the root

Continuing our work on the chemical constituents of $M$. salicifolia, the isolation of 4'-O-methylepigallocatechin (1) and proanthocyanidin A (2), compounds that were also isolated from other species of the Celastraceae family, ${ }^{23,25}$ is presently reported. The structural elucidation of these compounds was carried out using ${ }^{1} \mathrm{H}$ and ${ }^{13} \mathrm{C}$ NMR techniques, whose chemical shift assignments were very compatible with spectral data available in the literature. ${ }^{26}$

Based on the use of this species in Brazilian traditional medicine, extracts and constituents isolated from $M$. salicifolia were subjected to in vitro assays to verify its effect on oral pathogens $C$. albicans, S. mutans, $S$. sanguinis and $S$. aureus that are fungi and bacteria commonly found in the oral cavity, and $H$. pylori, which is associated to ulcer and other gastrointestinal disorders.

\section{Materials and Methods}

\subsection{General experimental procedures}


${ }^{1} \mathrm{H}$ and ${ }^{13} \mathrm{C}$ NMR spectra were run on a Bruker Avance DRX 400 spectrometer. The samples were dissolved in $\mathrm{CDCl}_{3}$ and TMS was used as internal standard. IR (film) spectra were recorded on a Bruker IFS 55 spectrophotometer, and UV spectra were performed on a Jasco V-560 spectrophotometer, for a sample dissolved in absolute EtOH. The column chromatography (CC) processes were carried out using silica gel 60 (Merck, 70-230 Mesh) and Sephadex LH-20 (Pharmacia). For the TLC analyses Sil 20 UV254, Panreac plates were used.

\subsection{Plant material}

M. salicifolia Reissek (Celastraceae) was collected from 'Serra de Ouro Branco', a mountain located in the Ouro Branco City region, MG, Brazil. The plant was identified by Dra. Rita Maria Carvalho-Okano, botanist of the Universidade Federal de Viçosa, MG, Brazil. A voucher specimen was deposited at the Herbarium José Badini of the Universidade Federal de Ouro Preto, MG, Brazil (Collection №. OUPR-18094). After collection, each part of the plant was separated and dried over kraft paper at room temperature (r.t.).

\subsection{Extraction and compound isolation}

The root bark of M. salicifolia (678.0 g) was subjected, at r.t., to exhaustive extraction with $n$-hexane, chloroform, ethyl acetate and finally with ethanol. After solvents removal at reduced pressure, the hexanic (HRE), chloroformic (CRE), ethyl acetate (ARE) and ethanolic (ERE) extracts were obtained. An aliquot (2.78 g) obtained from ethyl acetate extract (ARE, $9.6 \mathrm{~g}$ ) was chromatographed on Sephadex LH-20 CC, eluted with a mixture of dichloromethaneacetone (3:2), and 26 fractions of $125 \mathrm{~mL}$ each were collected. Based on the similar profile observed by means of TLC, three groups of fractions were obtained. Due to its complexity, verified through TLC and the small amount $(<15 \mathrm{mg})$ group 1 was discharged. From group 2 (208.5 mg) proanthocyanidin A (2) was isolated, which corresponds to $7.5 \%$ of the aliquot. Group 3 was characterized as a red dark amorphous solid $(417.0 \mathrm{mg})$, identified as $4^{\prime}-O$ methylepigallocatechin (1), corresponding to $15 \%$ of the aliquot. In relation to ARE, compound 1 represented to $4.34 \%$ and 2 corresponded to $2.17 \%$.

The compounds $\mathbf{3}$ to $\mathbf{7}$ were obtained from chloroform extract of root (CRE) bark of M. salicifolia as described in our previous work. ${ }^{21}$

The ethanolic extract from root bark (ERE; $86.4 \mathrm{~g}$ ) of $M$. salicifolia was obtained as a brown amorphous solid. An aliquot of this solid material (300 $\mathrm{mg}$ ) was subjected to silica gel $\mathrm{CC}$, eluted with $\mathrm{CH}_{2} \mathrm{Cl}_{2}$ - AcOEt in mixtures of increasing polarity, furnishing 47 fractions of $10 \mathrm{~mL}$. Based on the TLC profile, fractions 21-29 were combined and gave compound 1 (20.0 mg), corresponding to 6.7 $\%$ of this aliquot $(0.023 \%$ of ERE).

The branches of $M$. salicifolia (678.0 g) were also subjected, at r.t., to exhaustive extraction with $n$-hexane, $\mathrm{CHCl}_{3}$, ethyl acetate and finally with ethanol. The ethyl acetate extract obtained (ABE; $54.8 \mathrm{~g}$ ) was fractioned through silica-gel $60 \mathrm{CC}$, using $\mathrm{CH}_{2} \mathrm{Cl}_{2}-$ AcOEt as eluent in mixtures of increasing polarity, furnishing nineteen fractions of $500 \mathrm{~mL}$ each. Based on the similar profile observed through TLC, 7 groups of fractions were obtained. Group 4 gave $1(2.28 \mathrm{~g}, 4.16 \%$ of this extract). From group 6 (23.59 g), a portion of $7.79 \mathrm{~g}$ was separated which was subjected to sephadex $\mathrm{LH}-20 \mathrm{CC}$, eluted to $\mathrm{CHCl}_{3}-\mathrm{MeOH}$ (1:1). Fortytwo fractions were obtained. Based on the TLC profile, fractions 26-30 (1.72 g) were combined. A part of this group (255 $\mathrm{mg}$ ) was submitted to silica-gel 60 flash CC using $\mathrm{CH}_{2} \mathrm{Cl}_{2}$-AcOEt as eluent in mixtures of increasing polarity, furnishing 40 fractions, which were grouped according to TLC profile. Group 1 gave rise to additional amount of compound 1 (23.0 mg), corresponding to $9.02 \%$ of this portion. Group 3 was characterized as compound 2 (20.0 mg, 7.84 
$\%$ of this aliquot, $0.26 \%$ of $A B E$ ). From the ethanolic extract (EBE), no compounds with suitable purity for NMR analysis were isolated.

\subsection{Anti oral pathogens activity}

The polar and non-polar extracts from roots (ERE, HRE) and branches ( $\mathrm{ABE}, \mathrm{EBE}$ ) of $M$. salicifolia were evaluated against the oral pathogens Candida albicans (ATCC 18804), Streptococcus mutans (ATCC 70069), Streptococcus sanguinis (ATCC 10557) and Staphylococcus aureus (ATCC 12692). Samples of HRE, ERE, ABE and EBE were diluted in ethanol to reach concentrations of 50,100 and $200 \mathrm{mg} / \mathrm{mL}$. The antimicrobial assays were carried out using the agar diffusion method. ${ }^{27,28}$ Sterile blank discs treated with $20.0 \mu \mathrm{L}$ of nystatin 1.000.000UI (Nys) $\left(\right.$ Sigma $^{\circledR}$, USA) or chlorhexidine $0.12 \%$ (Chlor) (Sigma ${ }^{\circledR}$, USA) were respectively used as growth inhibition positive control. Discs treated with ethanol $70 \%$, or distilled water, were used as negative controls. The assays, in triplicate, were repeated three times, in different moments. After a 24-hour incubation period at $35{ }^{\circ} \mathrm{C}$, the diameters $(\mathrm{mm})$ of growth inhibition zone induced by the samples of $M$. salicifolia were measured and compared with the antimicrobial standards: Nys and Chlor. The microorganisms were considered sensitive when the diameter of the inhibition zone presented values not $3 \mathrm{~mm}$ shorter than the positive control; moderately sensitive when the inhibition zone was bigger than $2 \mathrm{~mm}$, but over $3 \mathrm{~mm}$ shorter than the positive control, and resistant when the diameter of the inhibition zone was $\leq 2 \mathrm{~mm}^{29}$ The results were expressed as the median (M) \pm standard deviation (SD). Minimum inhibitory concentration (MIC) was determined as the lowest concentration of the extract that inhibited the growth of the microorganisms subjected to the in vitro assay using the agar dilution method. ${ }^{27,28}$

\subsection{Anti H. pylori activity}

Compounds $\mathbf{3}$ to $\mathbf{7}$ (Figure 2), previously isolated from $M$. salicifolia, ${ }^{21}$ were subjected to in vitro assays against $H$. pylori (INCQS 00380). The culture of $H$. pylori incubated for 72 hours in soyabean casein digest medium (tryptone soya broth) was standardized by means of spectrophotometer, to reach final concentration of $1.33 \times 10^{8} \mathrm{UFC} / \mathrm{mL}\left(4.0 \times 10^{6}\right.$ UFC/well). The bioassays were carried out in 96 well microplates, for all compounds, in five folds.

The samples were added to the wells from a $500 \mu \mathrm{g} / \mathrm{mL} \quad(50 \mu \mathrm{g} / \mathrm{well}$ and final concentration of $250 \mu \mathrm{g} / \mathrm{mL}$ ) solution, in tryptone soya broth. After that, $70 \mu \mathrm{L}$ of the bacterium inoculum was added. The plates were incubated at $37{ }^{\circ} \mathrm{C}$ for 48 and $72 \mathrm{~h}$. Negative (tryptone soya broth) and positive (ampicillin) controls were tested simultaneously. The inhibition growth percentage was determined for spectrophotometric reading at $630 \mathrm{~nm}$ using a micro-ELISA (Infinite M200, Tecan). Visual qualitative reading of microbial growth was also carried out using methylene blue 0.2 $\mathrm{mg} / \mathrm{L}$ solution.

\section{Results and Discussion}

The ethyl acetate and ethanol extracts obtained from root bark (ARE and ERE) and branches (ABE) of $M$. salicifolia were subjected repeatedly to silica gel chromatographic processes, yielding the Known flavonoids 4'-Omethylepigallocatechin (1) and proanthocyanidin A (2) (Figure 2). The ${ }^{1} \mathrm{H}$ and ${ }^{13} \mathrm{C}$ NMR chemical shift assignments attributed to $\mathbf{1}$ and $\mathbf{2}$ (Spectral data in Supplementary Material) were in accordance with spectral data previously published. ${ }^{26}$ For the first time, these compounds in the roots of this species have been reported. The amounts found for 1 (8.81\%) and 2 (2.43\%) were considered significant and contribute to 
the use of $M$. salicifolia as an alternative source of these compounds, which show antioxidant properties. ${ }^{30}$ Certainly, the presence of these constituents, together with other flavonoids in the Maytenus species represent a determinant role in antiulcer and/or inhibition of gastric acid secretion processes, ${ }^{25,31}$ and support the use of $M$. salicifolia in Brazilian traditional medicine for the treatment of stomach diseases.

Due to the antimicrobial properties attributed to pentacyclic triterpenes and quinonemethides ${ }^{32-33}$ the lupanes nepeticin (3), rigidenol (4), glochidone (5), 11 $\alpha$ hydroxyglochidone (6) and the quinone methide $16 \beta$-hydroxypristimerin (7) (Figure 2) previously isolated from $M$. salicifolia, ${ }^{21}$ were subjected to in vitro assays to evaluate its properties against the pathogenic gastrointestinal bacteria $H$. pylori. Compounds $\mathbf{4}$ and $\mathbf{7}$ showed potential for $\mathrm{H}$. pylori inhibition, with $\mathbf{7}$ being the most active (Table 1 ). In the assay conditions no activity was detected for the other lupane triterpenes. The active compounds $\mathbf{4}$ and $\mathbf{7}$, associated to flavonoids $\mathbf{1}, \mathbf{2}$, and/or other constituents previously identified in $M$. salicifolia, such as pinostrobin and ferruginol, ${ }^{21}$ which display the same activity, ${ }^{34,35}$ support the popular use of this plant. In addition, M. salicifolia is used as an infusion, which should be mainly constituted by phenolic compounds that are correlated to popular treatments of gastrointestinal disorders.<smiles>COc1c(O)cc([C@H]2Oc3cc(O)cc(O)c3[C@@H](O)[C@@H]2O)cc1O</smiles>

1<smiles>COc1c(O)cc([C@H]2Oc3c(O)cc(O)c4c3O[C@@]4([C@H](O)c3ccc(O)cc3)c3cc(O)cc(O)c3[C@@H](O)[C@H]2O)cc1O</smiles>

2

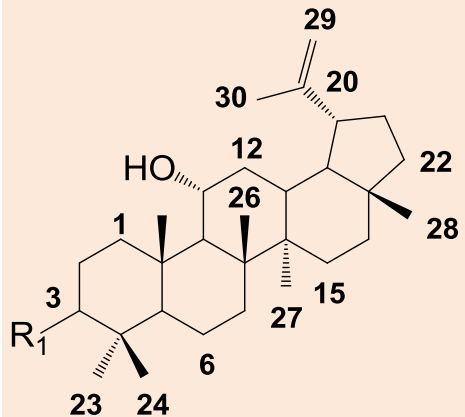

$23 \quad 24$

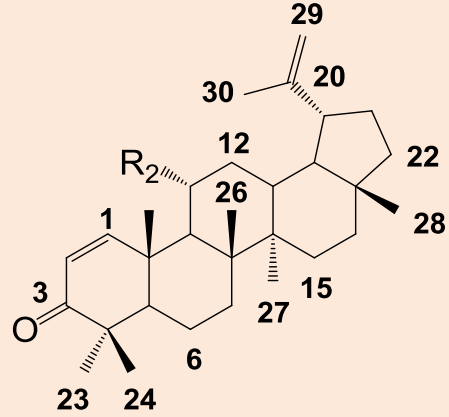

$\mathrm{R}_{2}: \mathrm{H} \quad \mathrm{R}_{2}: \mathrm{OH}$

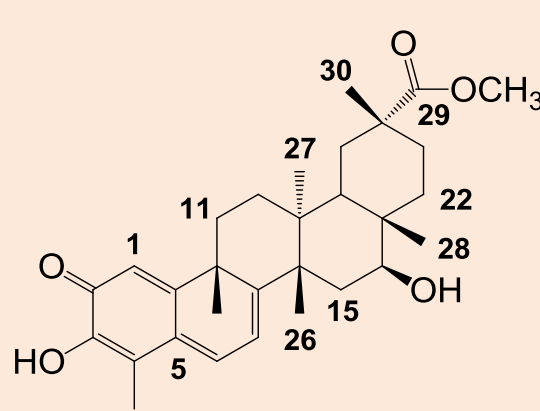

23

$$
\mathrm{R}_{1}:=\mathrm{OH} \quad \mathrm{R}_{1}:=\mathrm{O}
$$

3
4
6
7

Figure 2. Chemical structure of compounds $\mathbf{1}$ to $\mathbf{7}$ isolated from $M$. salicifolia 
Table 1. In vitro inhibition of $H$. pylori growth induced by pentacyclic triterpenes and quinonemethides isolated from M. salicifolia

\begin{tabular}{ccc}
\hline Sample & \multicolumn{2}{c}{ Growth inhibition $(\% \mathrm{M} \pm \mathrm{SD})$} \\
$(250 \mathrm{~g} / \mathrm{mL})$ & $48 \mathrm{~h}$ & $72 \mathrm{~h}$ \\
\hline Nepeticin (3) & $\mathrm{nd}$ & $\mathrm{nd}$ \\
Rigidenol (4) & $26.0 \pm 7.0$ & $24.0 \pm 6.0$ \\
Glochidone (5) & $\mathrm{nd}$ & $\mathrm{nd}$ \\
$11 \alpha$ P Hydroxyglochidone (6) & $\mathrm{nd}$ & $\mathrm{nd}$ \\
$16 \beta$-Hydroxypristimerin (7) & $84.0 \pm 4.0$ & $73.0 \pm 4.0$ \\
Ampicillin (Positive control) & $100.0 \pm 6.0$ & $82.0 \pm 8.0$ \\
\hline
\end{tabular}

$\mathrm{nd}=$ not detected in the assay conditions

Mean and Standard Deviation $(\mathrm{M} \pm \mathrm{SD})$ inhibition zones

The results of antimicrobial assays using extracts of $M$. salicifolia obtained from its branches treated with ethyl acetate (ABE) and from its roots treated with hexane (HRE) and with ethanol (ERE) against oral pathogenic microorganisms are presented in Table 2. All extracts of $M$. salicifolia presented properties that inhibit the growth of all microorganisms subjected to assays. However, when the efficacy of the samples was compared to positive controls, activity variations were noticed. In comparison to nystatine, all extracts were considered moderately active against C. albicans, because the diameter of the respective inhibition zones was much higher than $2 \mathrm{~mm}$, but over $3 \mathrm{~mm}$ shorter than the control. When the inhibition of the growth of this yeast was compared to chlorhexidine $(0.12 \%)$, the sample ERE in all concentrations evaluated and HRE $(50 \mathrm{mg} / \mathrm{mL})$ were more active than that one.

In relation to the bacteria subjected to in vitro assays, was observed that $S$. mutans was seen to be sensitive to HRE in all concentrations evaluated. Regarding all other samples, moderate inhibition of this bacterium growth was observed. S. sanguinis was the most resistant microorganism, being sensitive only to HRE at concentrations of $200 \mathrm{mg} / \mathrm{mL}$. For all samples assayed, moderate activity was observed. The most pronounced inhibition of $S$. aureus growth was induced by ERE at concentration of 200 $\mathrm{mg} / \mathrm{mL}$ and $E B E$ at concentration of 50 $\mathrm{mg} / \mathrm{mL}$, and for HRE at concentrations $\geq 100$ $\mathrm{mg} / \mathrm{mL}$. For $A B E$, good growth inhibition activity against $S$. aureus at concentrations of $50 \mathrm{mg} / \mathrm{mL}$ and $200 \mathrm{mg} / \mathrm{mL}$ was observed. 
Table 2. Antimicrobial susceptibility of oral pathogenic microorganisms to $M$. salicifolia extracts. Mean and Standard Deviation $(\mathrm{M} \pm \mathrm{SD}$ ) inhibition zones. Chlor = chlorhexidine and Nys = nystatine, used as positive control

\begin{tabular}{|c|c|c|c|c|}
\hline \multirow{2}{*}{$\begin{array}{c}\text { Extracts of } \\
\text { M. salicifolia } \\
(\mathrm{mg} / \mathrm{mL})\end{array}$} & \multicolumn{4}{|c|}{ Diameter $(\mathrm{mm})$ of inhibition growth zone $(\mathrm{M} \pm \mathrm{SD})$} \\
\hline & C. albicans & S. mutans & S. sanguinis & S. aureus \\
\hline \multicolumn{5}{|l|}{ ERE* } \\
\hline 50 & $17.6 \pm 0.82$ & $12.3 \pm 1.15$ & $11.6 \pm 1.26$ & $12.0 \pm 0.00$ \\
\hline 100 & $18.0 \pm 0.00$ & $12.5 \pm 1.05$ & $11.3 \pm 1.03$ & $12.0 \pm 0.00$ \\
\hline 200 & $18.0 \pm 0.00$ & $12.3 \pm 0.35$ & $14.6 \pm 1.08$ & $12.6 \pm 1,32$ \\
\hline \multicolumn{5}{|l|}{$\mathrm{EBE}^{* *}$} \\
\hline 50 & $16.3 \pm 1.03$ & $14.0 \pm 0.00$ & $10.5 \pm 0.33$ & $12.5 \pm 1.35$ \\
\hline 100 & $14.5 \pm 0.13$ & $14.0 \pm 0.00$ & $12.3 \pm 1.25$ & $12.0 \pm 0.00$ \\
\hline 200 & $14.0 \pm 0.00$ & $12.3 \pm 0.13$ & $11.6 \pm 1.44$ & $11.0 \pm 0.00$ \\
\hline \multicolumn{5}{|l|}{$\mathrm{ABE} * * *$} \\
\hline 50 & $12.0 \pm 0.00$ & $13.5 \pm 0.55$ & $13.0 \pm 0.00$ & $12.5 \pm 0.35$ \\
\hline 100 & $11.5 \pm 0.13$ & $14.5 \pm 0.35$ & $13.0 \pm 0.00$ & $12.0 \pm 0.00$ \\
\hline 200 & $10.5 \pm 1.03$ & $12.0 \pm 0.00$ & $10.5 \pm 0.00$ & $13.0 \pm 0.00$ \\
\hline \multicolumn{5}{|l|}{$\mathrm{HRE}^{* * * *}$} \\
\hline 50 & $19.3 \pm 0.33$ & $16.4 \pm 0.22$ & $13.3 \pm 0.39$ & $11.5 \pm 0.13$ \\
\hline 100 & $14.0 \pm 0.00$ & $17.0 \pm 0.00$ & $14.5 \pm 1.26$ & $13.0 \pm 0.00$ \\
\hline 200 & $13.0 \pm 0.00$ & $17.0 \pm 0.00$ & $15.0 \pm 0.00$ & $13.5 \pm 0.55$ \\
\hline Chlor (0.12\%) & $14.5 \pm 0.15$ & $18.8 \pm 0.14$ & $17.6 \pm 0.22$ & $15.0 \pm 0.00$ \\
\hline Nys $1.000 .000 \mathrm{Ul}$ & $22.9 \pm 0.64$ & - & - & - \\
\hline Ethanol 70\% & $0.00 \pm 0.00$ & $0.00 \pm 0.00$ & $0.00 \pm 0.00$ & $0.00 \pm 0.00$ \\
\hline Distilled water & $0.00 \pm 0.00$ & $0.00 \pm 0.00$ & $0.00 \pm 0.00$ & $0.00 \pm 0.00$ \\
\hline
\end{tabular}

*ERE: ethanolic extract of roots

**EBE: ethanolic extract of branches

*ABE: ethylacetate extract of branches

*HRE: hexanic extract of roots

The results related to minimum inhibitory concentration (MIC) found for the microorganisms (Table 3), ranged from 10.0 to $44.0 \mathrm{mg} / \mathrm{mL}$. The variation of MIC observed for $C$. albicans oscillated between 10.0 to $22.0 \mathrm{mg} / \mathrm{mL}$, which was considered the most susceptible among the microorganisms treated with extracts of $M$. 
salicifolia. The most susceptible bacterial strain was the cariogenic pathogen S. mutans (MIC ranging from 11.0 to $40.0 \mathrm{mg} / \mathrm{mL}$ ), followed by $S$. sanguinis (MIC varying between 20.0 to $44.0 \mathrm{mg} / \mathrm{mL}$ ). S. aureus was the less sensitive bacterium to $M$. salicifolia extracts (MIC $=40.0$ to $44.0 \mathrm{mg} / \mathrm{mL}$ ). For the positive controls used, chlorexidine MIC was $0.02 \mathrm{mg} / \mathrm{mL}$ and nystatine MIC was 0.004 $\mathrm{mg} / \mathrm{mL}$.

Table 3. Minimum inhibitory concentration (MIC) of $M$. salicifolia extracts tested against oral pathogenic microorganisms by means of micro-dilution method. Chlor $=$ chlorhexidine and Nys = nystatine, used as positive control

\begin{tabular}{ccccccc}
\hline \multirow{2}{*}{ Microorganisms } & \multicolumn{7}{l}{ MIC $(\mathrm{mg} / \mathrm{mL})$ of M. salicifolia } & extracts & \\
\cline { 2 - 7 } & ERE* & EBE** & ABE*** & HRE**** & Chlor & Nys \\
\hline C. albicans & 10.0 & 10.0 & 10.0 & 22.0 & - & 0.004 \\
S. aureus & 40.0 & 40.4 & 40.0 & 44.0 & 0.02 & - \\
S. mutans & 11.0 & 40.2 & 40.0 & 11.0 & 0.02 & - \\
S. sanguinis & 44.0 & 40.2 & 20.0 & 44.0 & 0.02 & - \\
\hline
\end{tabular}

*ERE: ethanolic extract of roots

**EBE: ethanolic extract of branches

***ABE: ethylacetate extract of branches

$* * * *$ HRE: hexanic extract of roots

The HRE activity can be associated with tingenone and lupeol, which were previously isolated from this hexanic extract ${ }^{21}$ and from other species belonging to family Celastraceae. Antimicrobial properties have been already attributed to tingenone and lupeol. ${ }^{36,37}$ The occurrence of $4^{\prime}-O$ methylepigallocatechin and proanthocyanidin A in polar extracts from $M$. salicifolia and from other species belonging to $M$. genus justifies the antimicrobial activity herein observed, which corroborated previously data reported for these compounds. ${ }^{38,39}$

\section{Conclusions}

In this work is described for the first time the occurrence of 4'-Omethylepigallocatechin (1) and proanthocyanidin A (2) in the roots of $M$. salicifolia and the expressive activity of $M$. salicifolia extracts against oral pathogens. The active compounds rigidenol (4) and $16 \beta$ hydroxypristimerin (7) against $H$. pylori contributed to the scientific support for the popular use of this species in the treatment of ulcer and other gastrointestinal disorders. These results showed that $M$. salicifolia can be a promising basis for further investigation in the discovery of new natural antibiotic compounds.

\section{Aknowlegments}

The authors are thankful to Conselho Nacional de Desenvolvimento Científico e Tecnológico (CNPq), Coordenação de Aperfeiçoamento de Pessoal de Nível Superior (CAPES) and Fundação de Amparo à Pesquisa do Estado de Minas Gerais 
(FAPEMIG) for financial support. Thanks to Dra Rita Maria Carvalho-Okano (Departamento de Botânica, Universidade Federal de Viçosa) for collecting and identifying the botanical material.

\section{References}

${ }^{1}$ Pereira, E. M. R.; Gomes, R. T.; Freire, N. R.; Aguiar, E. G.; Brandão, M. G. L.; Santos, V. R. In vitro antimicrobial activity of Brazilian medicinal plant extracts against pathogenic microorganisms of interest to dentistry. Planta Medica 2011, 77, 401. [CrossRef] [PubMed]

${ }^{2}$ Krumina, G.; Ratkevicha, L.; Nikolajeva, V.; Babarikina, A.; Babarykin, D. Influence of plant extracts on the growth of oral pathogens Streptococcus mutans and Candida albicans in vitro. Proceedings of the Estonian Academy of Sciences 2015, 64, 62. [CrossRef]

${ }^{3}$ Xu, P.; Alves, J. M.; Kitten, T.; Brown, A.; Chen, Z.; Ozaki, L. S.; Manque, P.; Ge, X.; Serrano, M. G.; Puiu, D. S.; Wang, Y.; Chaplin, M. D.; Akan, D.; Paik, S.; Peterson D. L.; Macrina F. L.; Buck, G. A. Genome of the opportunistic pathogen Streptococcus sanguinis. Journal of Bacteriology 2007, 189, 3166. [CrossRef] [PubMed]

${ }^{4}$ Kouidhi B.; Al Qurashi, Y. M. A.; Kamel Chaieb, K. Drug resistance of bacterial dental biofilm and the potential use of natural compounds as alternative for prevention and treatment. Microbial Pathogenesis 2015, 80, 39. [CrossRef]

${ }^{5}$ Porto, T. S.; Rangel, R.; Furtado, N. J. A. C.; Carvalho, T. C.; Martins, C. G. H.; Veneziani, R. C. S.; Da Costa, F.B.; Vinholis, A. H. C.; Cunha, W. R.; Heleno V. C. G.; Ambrosio, S. R. Pimarane-type diterpenes: antimicrobial activity against oral pathogens. Molecules 2009, 14, 191. [CrossRef] [PubMed]

${ }^{6}$ Geethangili, M.; Fang, S.; Lai, C.; Rao, Y. K.; Lien, $\mathrm{H}$.; Tzeng, Y. Inhibitory effect of Antrodia camphorata constituents on the Helicobacter pylori-associated gastric inflammation. Food Chemistry 2010, 119, 149. [CrossRef]
${ }^{7}$ Espinosa-Rivero, J.; Rendón-Huerta, E.; Romero, I. Inhibition of Helicobacter pylori growth and its colonization factors by Parthenium hysterophorus extracts. Journal of Ethnopharmacology 2015,174, 253. [CrossRef] [PubMed]

${ }^{8}$ Uemura, N.; Okamoto, S.; Yamamoto, S.; Matsumura, N.; Yamaguchi, S.; Yamakido, M.; Taniyama, K.; Sasaki, N.; Schlemper, R. J. Helicobacter pylori infection and the development of gastric cancer. The New England Journal of Medicine 2001, 345, 784. [CrossRef] [PubMed]

${ }^{9}$ Peek Jr, R. M.; Crabtree, J. E. Helicobacter infection and gastric neoplasia. Journal of Pathology 2006, 208, 233. [CrossRef] [PubMed]

${ }^{10}$ Romero-Gallo, J.; Harris, E. J.; Krishna, U.; Washington, M. K.; Perez-Perez G. I.; Peek, R. M. Effect of Helicobacter pylori eradication on gastric carcinogenesis. Laboratory Investigation 2008, 88, 328. [CrossRef][PubMed]

${ }^{11}$ Cogo, L. L.; Monteiro, C. L. B.; Miguel, M. D.; Miguel, O. G.; Cunico, M. M.; Ribeiro, M. L.; Camargo, E. R.; Kussen, G. M. B.; Nogueira, K. S.; Costa, L. M. D. AntiHelicobacter pylori activity of plant extracts traditionally used for the treatment of gastrointestinal disorders. Brazilian Journal of Microbiology 2010, 41, 304. [CrossRef] [PubMed]

${ }^{12}$ Silva, F. C.; Duarte, L. P.; Vieira Filho, S. A. Celastráceas: Fontes de Triterpenos Pentacíclicos com Potencial Atividade Biológica. Revista Virtual de Química 2014, 6, 1205. [CrossRef]

${ }^{13}$ Santos-Oliveira, R.; Coulaud-Cunha, S.; Colaço, W. Revisão da Maytenus ilicifolia Mart. ex Reissek, Celastraceae. Contribuição ao estudo das propriedades farmacológicas. Revista Brasileira de Farmacognosia 2009, 19, 650. [CrossRef]

${ }^{14}$ Jorge, R. M.; Leite, J.P.V.; Oliveira , A.B. ; Tagliati , C. A. Evaluation of antinociceptive, anti-inflammatory and antiulcerogenic activities of Maytenus ilicifolia. Journal of Ethnopharmacology 2004, 94 , 93. [CrossRef] [PubMed]

${ }^{15}$ Ferreira, P. M.; Oliveira, C. N.; Oliveira, A. B.; Lopes, M. J.; Alzamora, F.; Vieira, M. A. R. 
A lyophilized aqueous extract of Maytenus ilicifolia leaves inhibits histamine-mediated acid secretion in isolated frog gastric mucosa. Planta 2004, 219, 319. [CrossRef] [PubMed]

${ }^{16}$ Niero, R.; Faloni, S. D. A.; Cechinel, V. F. A review of the ethnopharmacology, phytochemistry and pharmacology of plants of the Maytenus genus. Current Pharmaceutical Design 2011, 17, 1851. [CrossRef] [PubMed]

${ }^{17}$ Morita, M.; Hirasawa, Y.; Muto, A.; Yoshida, T.; Sekita, S.; Shirota, O. Antimitotic quinoid triterpenes from Maytenus chuchuhuasca. Bioorganic and Medicinal Chemistry Letters 2008, 18, 1050. [CrossRef] [PubMed]

${ }^{18}$ Vellosa, J. C. R.; Khalil, N. M.; Formenton, V. A. F.; Ximenes, V. F.; Fonseca, L. M.; Furlan, M.; Brunetti, I. L.; Oliveira, O. M. M. F. Antioxidant activity of Maytenus ilicifolia root bark. Fitoterapia 2006, 77, 243. [CrossRef] [PubMed]

${ }^{19}$ Valladão, F. N.; Miranda, R. R. S.; Vale, F. H.; Valladão, S. A.; Silva, G. D. F.; Duarte, L. P.; Carvalho-Okano, R. M.; Messias, M. C. T. B.; Vieira-Filho, S. A. Four brazilian Maytenus salicifolia Reissek (Celastraceae) groups studied by TLC and UV/Vis spectrophotometry. Revista Brasileira de Farmacognosia 2009, 19, 733. [CrossRef]

${ }^{20}$ Magalhães, C. G.; Ferrari, F. C.; Guimarâes, D. A. S.; Silva, G. D. F.; Duarte, L. P.; Figueiredo, R. C.; Vieira Filho, S. A. Maytenus salicifolia Reissek, Celastraceae: triterpenes isolated from stems and antioxidant property of extracts from aerial parts. Revista Brasileira de Farmacognosia 2011, 21, 415. [CrossRef]

${ }^{21}$ Magalhães, C. G.; Silva, G. D. F.; Duarte, L. P.; Bazzocchi, I. L.; Diaz, A. J.; Moujir, L.; López, M. R.; Figueiredo, R. C.; Vieira Filho, S. A. . Salicassin, an unprecedented chalconediterpene adduct and a quinonemethide triterpenoid from Maytenus salicifolia. Helvetica Chimica Acta 2013, 96, 1046. [CrossRef]

${ }^{22}$ Duarte, L. P.; Vieira Filho, S. A.; Silva, G. D. F.; Sousa, J. R.; Pinto, A. S. Anti-trypanosomal activity of pentacyclic triterpenes isolated from Austroplenckia populnea (Celastraceae).
Revista do Instituto de Medicina Tropical de São Paulo 2002, 44, 109. [CrossRef] [PubMed]

${ }^{23}$ Oliveira, M. G. L.; Assenco, R. A. G.; Silva, G. D. F.; Lopes, J. C. D.; Silva, F. C.; Lanna, M. C. S.; Magalhães, J. C.; Duarte, L. P.; Vieira Filho, S. A. Cytotoxicity, anti-poliovirus activity and in silico biological evaluation of constituents from Maytenus gonoclada (Celastraceae). International Journal of Pharmaceutical Sciences 2014, 6, 130. [Link]

${ }^{24}$ Sousa, G. F.; Duarte, L. P.; Alcântara, A. F. C.; Silva, G. D. F.; Vieira Filho, S. A.; Silva R. R.; Oliveira, D. M.; Takahashi, J. A. New Triterpenes from Maytenus robusta: Structural Elucidation Based on NMR Experimental Data and Theoretical Calculations. Molecules 2012, 17, 13439. [CrossRef] [PubMed]

${ }^{25}$ Baggio, C. H.; Freitas, C. S.; Otofuji, G. M.; Cipriani, T. R.; de Souza, L. M.; Sassaki, G. L.; lacomini, M.; Marques, M. C. A.; Mesia-Vela, S. Flavonoid-rich fraction of Maytenus ilicifolia Mart. ex. Reiss protects the gastric mucosa of rodents through inhibition of both $\mathrm{H}^{+}, \mathrm{K}^{+}$-ATPase activity and formation of nitric oxide. Journal of Ethnopharmacology 2007, 113, 433. [CrossRef] [PubMed]

${ }^{26}$ Aguiar, R. M.; David, J. P.; David, J. M. Unusual naphthoquinones, catechin and triterpene from Byrsonima microphylla. Phytochemistry 2005, 66, 2388. [CrossRef] [PubMed]

${ }^{27}$ Ferraro, M. J.; Wikler, M. A.; Craig, W. A.; Dudley, M. N.; Eliopoulos, G. M.; Hecht, D. W.; Hindler, J.; Reller, L. B.; Sheldon, A. T.; Swenson, J. M.; Tenover, F. C.; Testa, R. T.; Weinstein, M. P. Performance Standards for Antimicrobial Disk Susceptibility Tests; Approved Standard, 8th. ed, V. 23, Pennsylvania: Clinical and Laboratory Standards Institute (CLSI), 2003.

${ }^{28} \mathrm{CLSI}$ (Clinical Laboratory Standards Institute). Reference method for broth dilution antifungal susceptibility testing of yeasts, 2nd. ed, Wayne: Clinical and 
Laboratory Standards Institute document M27-A2, 2007.

${ }^{29}$ Ostrosky, E. A.; Mizumoto, M. K.; Lima, M. E. L.; Kaneko, T. M.; Nishikawa, S. O.; Freitas, B. R. Métodos para avaliação da atividade antimicrobiana e determinação da concentração mínima inibitória (CMI) de plantas medicinais. Brazilian Journal of Pharmacognosy 2008, 18, 301. [CrossRef]

${ }^{30}$ Oldoni, T. L. C.; Melo, P. S.; Massarioli, A. P.; Moreno, I. A. M.; Bezerra, R. M. N.; Rosalen, P. L.; da Silva, G. V. J.; Nascimento, A. M.; Alencar, S. M. Bioassay-guided isolation of proanthocyanidins with antioxidant activity from peanut (Arachis hypogaea) skin by combination of chromatography techniques. Food Chemistry 2016, 192, 306. [CrossRef] [PubMed]

${ }^{31}$ Hamaishi, K.; Kojima, R.; Ito, M. Anti-ulcer effect of tea catechin in rats. Biological and Pharmaceutical Bulletin 2006, 29, 2206. [CrossRef] [PubMed]

${ }^{32}$ De León, L.; Beltrán, B.; Moujir, L. Antimicrobial activity of 6-oxophenolic triterpenoids. Mode of action against Bacillus subtilis. Planta Medica 2005, 71, 1. [CrossRef] [PubMed]

${ }^{33}$ Sakava, P.; Talla, E.; Chelea, M.; Tchinda, A. T.; Zeuko'o, E. M.; Laurent Sophie, L.; Vander, L. E.; Tagatsing, M. F.; Yaya, J. A. G, Atchade, A. T.; Mbafor, J. T. Pentacyclic triterpenes and crude extracts with antimicrobial activity from Cameroonian brown propolis samples. Journal of Applied Pharmaceutical Science 2014, 4, 1. [CrossRef]
${ }^{34}$ Espinoza, M.; Santos, L. S.; Theoduloz, C.; Schmeda-Hirschmann, G.; Rodríguez, J. A. New gastroprotective ferruginol derivatives with selective cytotoxicity against gastric cancer cells. Planta Medica 2008, 74, 802. [CrossRef][PubMed]

${ }^{35}$ Abdelwahab, S. I.; Mohan, S.; Abdulla, M. A.; Sukari, M. A.; Abdul, A. B.; Taha, M. M. E.; Suvitha, S.; Ahmad, S.; Leef, K. H. The methanolic extract of Boesenbergia rotunda (L.) Mansf. and its major compound pinostrobin induces anti-ulcerogenic property in vivo: possible involvement of indirect antioxidant action. Journal of Ethnopharmacology 2011, 137, 963. [CrossRef] [PubMed]

${ }^{36}$ Reyes, C. P.; Núñez, M. J.; Jiménez, I. A.; Busserolles, J.; Alcaraz, M. J.; Bazzocchi, I. L. Activity of lupane triterpenoids from Maytenus species as inhibitors of nitric oxide and prostaglandin E2. Bioorganic and Medicinal Chemistry 2006, 14, 1573. [CrossRef] [PubMed]

${ }^{37}$ Siddique, H. R.; Saleem, M. Beneficial health effects of lupeol triterpene: $A$ review of preclinical studies. Life Sciences 2011, 88, 285. [CrossRef] [PubMed]

${ }^{38}$ Cushnie, T. P. T.; Lamb, A. J. Recent advances in understanding the antibacterial properties of flavonoids. International Journal Antimicrobial Agents 2011, 38, 99. [CrossRef] [PubMed]

${ }^{39}$ Daglia, M. Polyphenols as antimicrobial agents. Current Opinion Biotechnology 2012, 23, 174. [CrossRef] [PubMed] 